\title{
COMPLEX MONITORING QUALITY OF PROFESSIONAL DEVELOPMENT FOR PEDAGOGICAL WORKERS OF SMALL SCHOOLS
}

Ayslu Akisheva', Aygul Zeynelova, Mara Makitova, Aliya Imanova

Orleu" Institute of Professional Development of Pedagogical Workers in Akmola region, Kokshetau, Kazakhstan

\section{ABSTRACT}

The article discusses the experience comprehensive monitoring of the effectiveness training teachers small schools. The aim is to determine the comprehensive monitoring of quality course preparation and post-cycle. Treatment monitoring studies makes it possible to identify the actual needs of teachers to organize and advance future efforts to improve the content training sessions and the teaching quality. It presents a synthesis of the study educational needs, expectations and degree readiness of students to learn during the upcoming training course. Research results obtained make it possible to identify the shortcomings in the work and comply with all the requirements of students. The facts and analytical report on the results of the monitoring.

\section{UDC \& KEYWORDS}

UDC: 37 SMALL SCHOOL PROFESSIONAL DEVELOPMENT COURSE PREPARATION MONITORING QUALITY EFFICIENCY

\section{INTRODUCTION}

Now, in Kazakhstan, the concept of development small schools works during 2010-2020 (Astana, 2011).

It shows the general strategy, the purpose and problems of a state policy in the field of development of small schools, the main directions of development and a condition of their realization. According to the State program of a development of education of the Republic of Kazakhstan for 2011-2020, in the conditions of education updating the special importance is gained by preparation of the pedagogical staff and the increase of their professional competence (State Programme, 2011-2020). The teacher working in specific conditions of schools with the small contingent of pupils has to possess a number of additional professional competences (Savinkov, 2012). The approaches to the organization of course training teachers working in small schools are defined according to the above-named documents in the education field in the system of professional development pedagogical staff of the Republic of Kazakhstan (Shcherbakova, 2012).

As the institution additional education, the branch "Orleu" "The institute of professional development in Akmola region" organizes the course training specialists of small schools for the purpose of improvement their pedagogical skill and educational activity quality.

For ensuring effective work of the professional development, determination quality of course training teachers of smal schools, the monitoring system of educational activity is organized in this branch (Monitoring of schools). Systemacity is traced in continuity of the carried-out monitoring: the complex work on tracking quality and efficiency of the carried-out work is conducted during the row of years. Approaches to a assessment of the quality in the mode of monitoring researches are based on studying । idt12@mail.ru the process of training and compliance of its results to the goals and requirements (Information system 2015).

For the purpose of definition complete picture quality and efficiency of activity monitoring actions are organized in two main directions:

1. analysis of course preparation;

2. monitoring post course activity teachers of small schools.

Thus, during 2013-2015, the branch "Orleu" "Institute of professional development of educators in Akmola region" organized course training teachers of the small schools of Akmola region and, the analitic and monitoring events for quality control of educational activity within the professional development are held along with that.

\section{The main part}

Analysis of course preparation

One of the parameters of monitoring defining demand degree in course preparation is the analysis of quantity of organized courses and coverage of teachers of small schools by them. According to analytical data the tendency of increase in quantity of the conducted courses, and also coverage of course training of teachers of small schools of the region, the gain of number of trainees for 3 years is $47 \%$. The data of monitoring testify about the increasing need for course preparation (Figure 1).

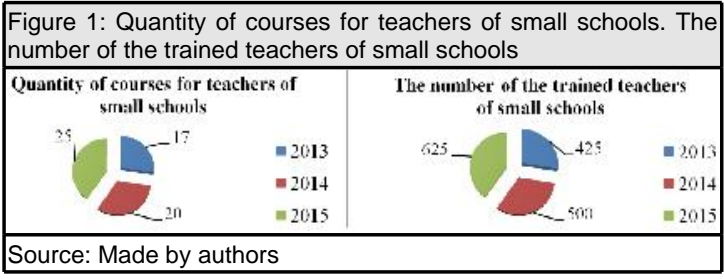

Besides, the analysis of coverage by advanced training courses of categories of pedagogical workers of small schools showed that 13 categories of listeners were trained during 3 years. The executives of establishments of education - directors and deputy directors of small schools, and also the subject teachers are among them (Table 1).

Further work on improvement of the content of course preparation and quality of teaching is based on the basis of complex data of monitoring of educational process and diagnostics of actual needs of teachers. The generalized analysis of studying of educational requirements, expectations and degree of readiness of listeners for training during the forthcoming course preparation showed the following tendencies.

The most actual purposes of training are "desire to increase the level of the professional skill", "aspiration to seize modern technologies, methods of training and education", "need for continuous training" and "increase of qualification category". And dynamics of growth of number of the listeners 


\begin{tabular}{|c|c|c|}
\hline № & Category & \begin{tabular}{|l|}
$\begin{array}{l}\text { The number } \\
\text { of courses }\end{array}$ \\
\end{tabular} \\
\hline 1 & Directors of small schools and evening schools & 4 \\
\hline 2 & $\begin{array}{l}\text { Directors of small schools with the length of service about } 3 \text { years. } \\
\text { Introduction into the position. }\end{array}$ & 2 \\
\hline 3 & Deputy directors of UVR and NMR small schools and evening schools & 4 \\
\hline 4 & English teachers of small schools and evening schools & 6 \\
\hline 5 & $\begin{array}{l}\text { Elementary school teachers of small schools and schools of complex } \\
\text { preparations }\end{array}$ & 6 \\
\hline 6 & Art teachers of small schools and schools of complex preparations, colleges & 4 \\
\hline 7 & $\begin{array}{l}\text { Teachers - subject teachers of schools of complex preparations and } \\
\text { general education and small schools }\end{array}$ & 6 \\
\hline 8 & Teachers of Russian and literature of small schools & 4 \\
\hline 9 & Teachers of the Kazakh language and literature of small schools & 6 \\
\hline 10 & Teachers of history of small schools & 4 \\
\hline 11 & Teachers of geography of small schools & 4 \\
\hline 12 & Teachers of mathematics of small schools and evening schools & 6 \\
\hline 13 & Teachers of chemistry and biology of small schools and evening schools & 6 \\
\hline & Total: 13 categories of listeners & 62 courses \\
\hline & urce: Made by authors & \\
\hline
\end{tabular}

specifying these purposes of professional development as priority is also traced (Figure 2).

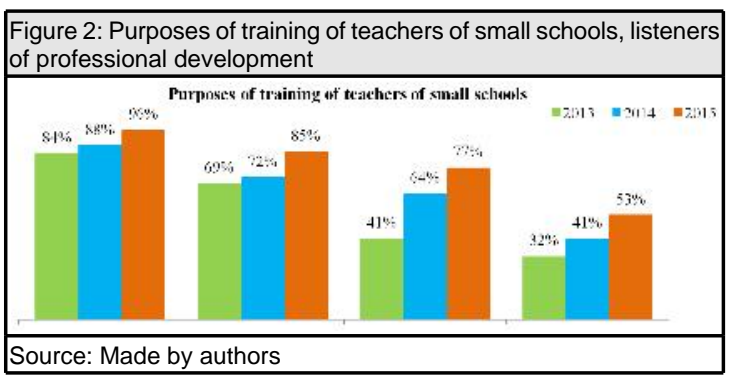

In an assessment of productive forms of education for increase of the level of professional competence, according to teachers of small schools, practice focused competence are the most preferable (Figure 3).

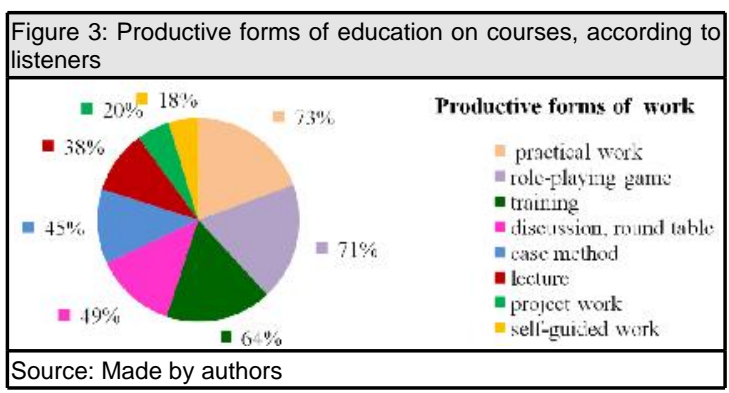

For an assessment of value of course training of teachers of small school, the fact that within all 3 years the tendency is traced is important, in which the listeners consider advanced training courses as the main source of obtaining information about innovative approaches to education (Figure 4).

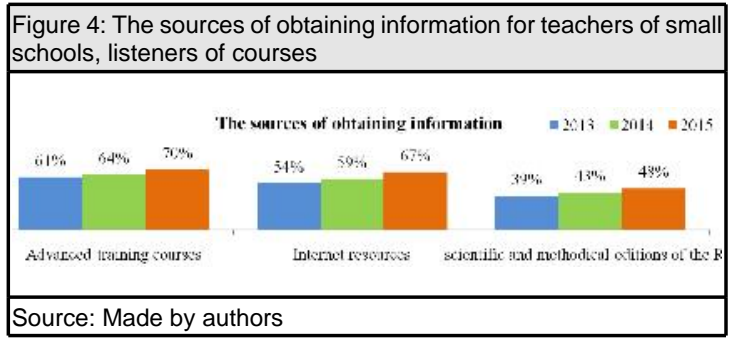

It is possible to judge quality of the organization of course preparation on that upon termination of training on courses listeners would like to keep in contact and interaction with institute in various forms, and the need for internal interaction with experts of IPK grows every year (Figure 5).

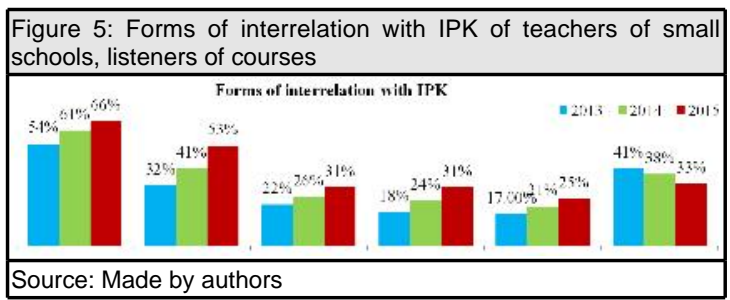

Other important parameter of monitoring of course training of teachers of small school is the analysis of control of knowledge of students (tests, project and independent works). The analysis of results of an assessment of academic performance rating during the period of 2013-2015 showed a tendency to the growth of quality of the performed works. The basic (initial) awareness of teachers on a subject of courses raised,not only the data of entrance testing, but also the quality of training following the results of output testing confirm that. The gain of knowledge of listeners also testifies to assimilation of a training material and quality of training (Figure 6).

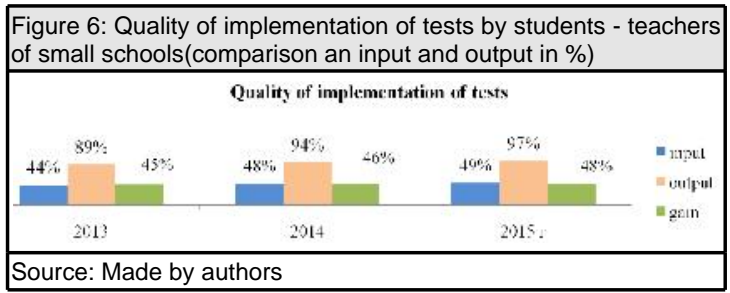

The comparative analysis of results of protection of projects and independent works of listeners according to the results of training of teachers of small schools of the region on courses also showed positive dynamics (Figure 7).

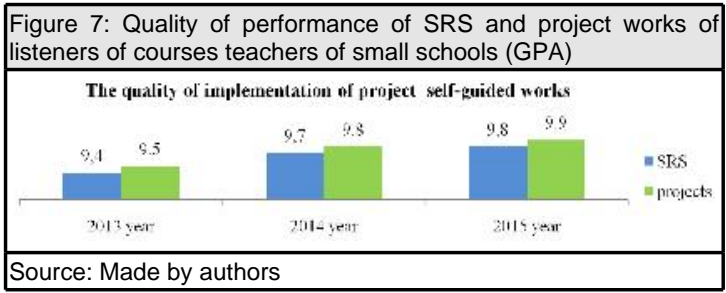

In general, the comparative analysis of the estimates data of control of the knowledge of course participants found the progress in development by listeners of programs of professional development with the specifics of small schools.

It is possible to judge the quality of the organization of course training of teachers of small schools according to the self-assessment of professional and personal changes of the listeners upon completion of training on the basis of data of the final questioning.

Achievement of the purpose of courses, professional and personal changes after completion of training are estimated by listeners rather positively. After completion of courses during 3 years, $100 \%$ of listeners - teachers of small schools have feeling of satisfaction (Figure 8). 


Figure 8: A self-assessment of the degree of satisfaction with
courses of the listeners - teachers of small schools.
What do you feel after compliting the courses?
Source: Made by authors

By the end of training listeners - teachers of small schools note the increase of professional growth (Figure 9).

\begin{tabular}{|c|c|c|c|}
\hline \multicolumn{4}{|c|}{$\begin{array}{l}\text { Figure 9: A self-assessment of professional growth of listeners - } \\
\text { teachers of small schools }\end{array}$} \\
\hline \multicolumn{4}{|c|}{ 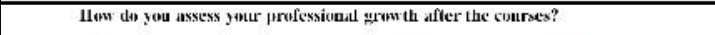 } \\
\hline $2 x^{20}{ }^{68 \%} \%$ & $48 \%, 52 \%$ & $54 \% 30 \%$ & 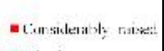 \\
\hline $213 \mathrm{y}$ & $2011 \%$. & $2015 \%$ & - bart fo so \\
\hline Source: Made & hors & & \\
\hline
\end{tabular}

During 3 years, $100 \%$ of listeners consider the purpose of courses was reached (Figure 10).

In this regard, all listeners see the novelty of courses.

\begin{tabular}{l} 
Figure 10: Self-assessment of achievement of the purpose of \\
courses by listeners - teachers of small schools \\
\hline
\end{tabular}

As a result of full achievement of the objectives of training, teachers of small schools note the changes in a view of the modern organization of the process of education at school (Figure 11).

Did you change your view to the modern organization of process of education? Is there any novelty in education?

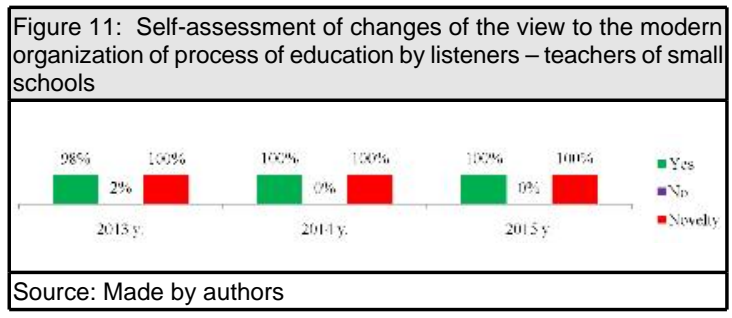

Thus, indicators of productivity and quality of course training of teachers of small schools testify to the positive dynamics of level of the organization of educational and methodical work in the system of professional development of Akmola region.

\section{Monitoring of post course activity of teachers of small schools}

Indicator of the efficiency of advanced training courses are the changes in practical activities of teachers, professionalism improvement, the educational potential realized by them, and, as a result, educational results of their pupils.

For definition of a complete picture of realization of system of professional development, the monitoring of post course activity of teachers of small schools will be organized.

Parameters of an assessment of efficiency of advanced training courses of teachers during the post course period are:

www.journals.cz
1. The increase of qualification category of teachers.

2. Application of innovative technologies, broadcast of the best practices and publication of teachers.

3. Participation of teachers in various educational projects and competitions.

4. Speeches of teachers at the seminars and conferences.

5. Publications of articles in pedagogical editions and mass media, the edition of textbooks, monographs, methodical grants and recommendations.

6. Progress and quality of knowledge of pupils.

7. Participation of pupils in the subject Olympic Games.

According to the results of monitoring increase of qualification category of pedagogical workers of small schools which testifies to the recognition of quality of work and results of pedagogical activity, its appreciation in the educational environment became an indicator of efficiency of course training (Figure 12).

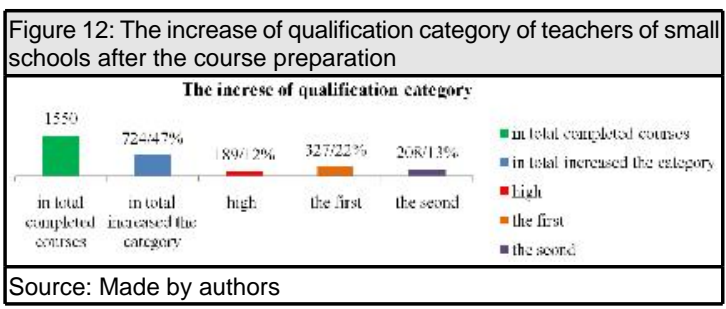

The data of feedback with participants of courses tell about efficiency of professional development of teachers of MKSh: most of teachers of small schools which had course training systemically use innovative technologies in educational process and that is reflected in its quality and productivity. As a result of application of pedagogical technologies, possibility of teachers to generalize own pedagogical experience and use it at various levels (Figure 13).

\begin{tabular}{|l|}
\hline $\begin{array}{l}\text { Figure 13: Use of innovative technologies by teachers of small } \\
\text { schools in educational process }\end{array}$ \\
\hline The use of innovative technologies \\
$1550-10 \% \%$
\end{tabular}

The indicator of efficiency of course preparation is also the growth of number of the published methodical products by teachers of small schools, among which are the methodical recommendations, grants, electronic and digital materials, the number of which grows every year (Figure 14).

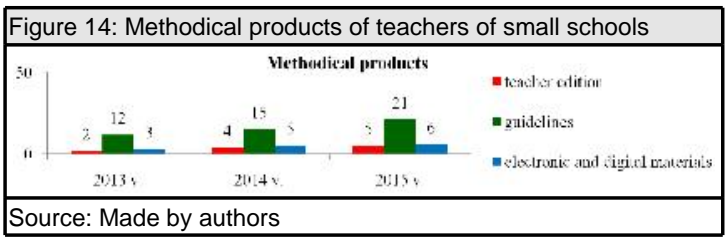

Important indicator of productivity of post-course activity of teachers is the quality of knowledge of pupils. Applying the knowledge and abilities gained on courses in pedagogical activity, enriching educational process with innovative methods and receptions, teachers are eventually capable to achieve the increase of quality of education. The 
tendency of growth of indicators of quality of education of pupils is noted according to the results of monitoring of post-course activity of teachers of small schools (Figure 15).

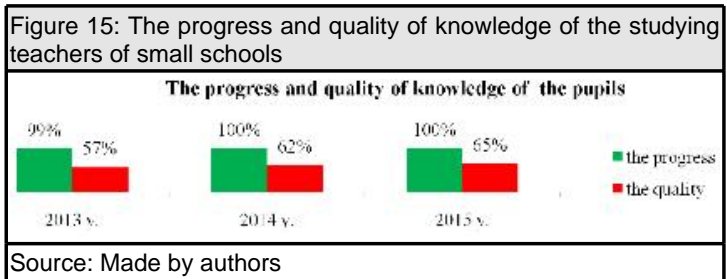

The activization of out-of-class work on a subject is one more indicator of the qualitative organization of process of training, so and one of "the delayed results" of the efficiency of education of teachers of small schools during course preparation. The growth of indicators is noted according to the results of the analysis of quality of participation of pupils in the subject Olympic Games (Figure 16).

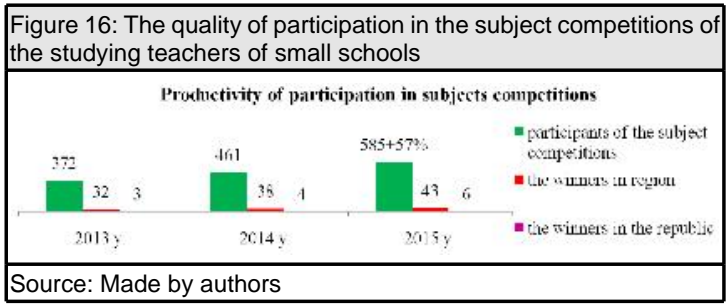

The data of monitoring of postcourse activity of teachers of small schools, listeners of short-term advanced training courses, testify to efficiency of course training at a stage of practical realization. The factor indicating improvement of quality and productivity of educational process and pedagogical activity of teachers of small schools, are the proof of their professional activity which acts as a result of increase of professional skill and "the delayed result" of training at advanced training courses.

\section{CONCLUSION}

Thus, the system of professional development plays an important role in improvement of professional skill of teachers of small schools in the conditions of education updating. The work on training of teachers of small schools which is carried out by the branch "Orleu" and "Institute of professional development in Akmola region" promotes their high-quality preparation and increase of professional competence. It finds confirmation in the data of the complex monitoring, quality of courses and productivity of postcourse activity.

The result of complex monitoring of quality of professional development of pedagogical workers of small schools is the conclusion about efficiency of the course preparation which became a basis for introduction by teachers of innovations in educational process and practice of training during the post-course period.

\section{REFERENCES}

Astana, 2011. The concept of small schools in the Republic of Kazakhstan for 2010-2020.

Information system 2015. For monitoring and organizational and pedagogical support activities of small schools and schools located in remote areas. http://www.little-school.ru/

Monitoring of schools working in difficult social conditions (small schools) http://www.irooo.ru/index.php/deyatelnost-tsentramonitoringa-i-otsenki-kachestva-obrazovaniya/itemlist/category/23 0-monitoring-shkol-rabotayushchikh-v-slozhnykh-sotsialnykh-uslov iyakh-malokomplektnye-shkoly

Savinkov, Y. A. 2012. Specific pedagogical competence of the teacher diversified rural small school: www.vestnik.vsu.ru

Shcherbakova, E. V. 2012. Small rural school: the current state, problems and prospects / E.V.Shcherbakova // Theory and practice of education in the modern world: Materials of the II Intern. scientific. Conf. (St. Petersburg, November). - SPb: Renome - pp. 107-109.

State Program for Development of the Republic of Kazakhstan for 2011-2020, http://adilet.zan.kz/rus/docs/U1000001118. 